\title{
Eucalyptus saxicola (Myrtaceae), a new species from the Central Tablelands of New South Wales (section Maidenaria series Bridgesianae)
}

\author{
John T. Hunter
}

\begin{abstract}
Hunter, John T. (75 Kendall Rd, Invergowrie, NSW 2350, Australia) 2001. Eucalyptus saxicola J.T. Hunter (Myrtaceae), a new species from the Central Tablelands of New South Wales (section Maidenaria series Bridgesianae) Telopea 9(2): 403-407. Eucalyptus saxicola J.T. Hunter, a new species from Mt Canobolas within the Central Tablelands of New South Wales is described and notes are provided on its distribution and conservation status. The species is distinguished from the similar Eucalyptus bridgesiana by its smaller buds and fruits and generally smaller stature and juvenile leaves.
\end{abstract}

\section{Introduction}

During a survey of the population size and distribution of Eucalyptus canobolensis in June 1998 (Hunter 1998), specimens were collected of an unusual eucalypt found restricted to the margins of acid volcanic outcrops near the summit of Mt Canobolas. A further investigation of this entity was conducted during a vegetation survey of the Mt Canobolas State Recreation Area (Hunter 2000), confirming its status as a highly restricted unnamed species. Although the morphologically similar Eucalyptus bridgesiana has been collected from Mt Canobolas in the past this highly restricted species had not previously been collected.

\section{Key to species}

An excerpt from the key to Eucalyptus species presented by Hill (1991) is amended to include E. saxicola.

Group 5

33 Juvenile leaves orbiculate.

33a Juvenile leaves $1.5-4 \mathrm{~cm}$ wide

E. saxicola

$33 a^{*}$ Juvenile leaves $4-8 \mathrm{~cm}$ wide

34 Fruit $>5 \mathrm{~mm}$ long

E. bridgesiana

$34^{*}$ Fruit $<5 \mathrm{~mm}$ long

E. nova-anglica

33* Juvenile leaves narrow-elliptic

E. ignorabilis

\section{Taxonomy}

Eucalyptus saxicola J.T. Hunter, sp. nov.

$\mathrm{Ab}$ E. bridgesiana habitu, foliis juvinalibus, alabastris fructibusque minoribus, et calyptris hemisphaericis differt. 
Type: New South Wales: Central Tablelands: Mt Canobolas State Recreation Area, c. 14 km

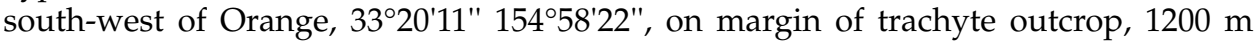
altitude, J.T. Hunter 8556, 2 June 1998 (holo NSW; iso BRI, CANB, MEL).

Small tree 6-15 $\mathrm{m}$ tall with a box bark persistent to larger branches, then shed in long strips. Stems terete, glandular to erect-warty on juvenile and sucker stems. Juvenile leaves orbicular becoming broadly ovate, glaucous, $1.5-4 \mathrm{~cm}$ long, $1.5-4 \mathrm{~cm}$ wide, margins crenulate and slightly recurved, opposite becoming subopposite at about the fourth internode, apex rounded and mucronate to shortly acute, base deeply cordate, sessile. Intermediate leaves broadly ovate elliptic to broad lanceolate, 4-13 cm long, 3-6.5 cm wide, falcate, alternate, \pm glaucous, apex acuminate and \pm hooked, base rounded to attenuate and oblique, with petioles $1-4 \mathrm{~cm}$ long. Adult leaves alternate, linear to narrow lanceolate, $12.5-23 \mathrm{~cm}$ long, $1.1-2.3 \mathrm{~cm}$ wide, with conspicuous oil dots, conspicuously glossy and dark green, never glaucous, falcate, margins entire, apex acuminate and often hooked, base attenuate and oblique, petiole terete to flattened, channeled, 2-4 cm long, venation 25-35 degrees to midrib, intramarginal vein $0.8-1.4 \mathrm{~mm}$ from the margin, midrib flat to channelled above. Inflorescence of 7-flowered axillary umbellasters. Peduncle flattened to ovoid in section, 1-4 $\mathrm{mm}$ long in bud, 3-9 $\mathrm{mm}$ long in fruit; pedicel 1-2.4 $\mathrm{mm}$ long in bud, absent or to $3 \mathrm{~mm}$ long in fruit. Buds turbinoid to clavoid, 3.5-4.5 mm long, 2.3-2.7 mm wide, not glaucous; calyptra hemispherical to shortly beaked hemispherical, $1.5-2.3 \mathrm{~mm}$ long, $2.3-2.7 \mathrm{~mm}$ wide; hypanthium obloid, 1.5-2.4 mm long, 2.2-2.6 mm wide. Ovules in 4 rows; style terete, 2-3 mm long. Stamens irregularly inflexed; filaments $2.5-3.5 \mathrm{~mm}$ long; anthers dorsifixed, parallel, $0.5-0.6 \mathrm{~mm}$ long, white, dehiscence longitudinal; connective oil gland orbicular and abaxial. Fruits hemispherical, 3.5-5.2 long, 4.3-6 mm wide, slightly ribbed, often splitting on one side, disc level to convex, $0.4-0.8 \mathrm{~mm}$ wide, scar distinct; valves 3-4, level to exserted. Seeds smooth to shallowly reticulate, red-brown to yellow-brown, cuboid, strongly angular, rounded terminal or central hilum on flat polygonal surface, $0.9-1 \mathrm{~mm}$ long, $0.5-0.8 \mathrm{~mm}$ wide. Cotyledons bilobed. (Fig. 1).

Selected specimens examined: New South Wales: Central Tablelands: Mt Canobolas State Recreation Area, c. $14 \mathrm{~km}$ south-west of Orange, on margin of trachyte outcrop, $1200 \mathrm{~m}$ altitude, Hunter 8568-8569, 3 June 1998; Hunter 17502, 20 Sept 1999; Hunter 17565, Bryant and Beckers, 23 Sept 1999 (all MEL, NSW).

Distribution: small and closely scattered stands of Eucalyptus saxicola occur on the northern slope of Mt Canobolas near the summit. The species dominates the shallow soils on acid volcanic outcrops and their margins. The population is only known from a handful of small outcrops scattered over a distance of about $1 \mathrm{~km}$ long and $0.3 \mathrm{~km}$ wide. These populations are dissected by three major access roads to the summit.

Habitat: Eucalyptus saxicola is found in open and exposed situations on and around the margins of trachytic rock outcrops between 1150-1300 m above sea level. The mean annual rainfall of this area is $850-950 \mathrm{~mm}$. Associated species include Eucalyptus canobolensis in the overstorey and Cassinia uncata, Phebalium squamulosum, Mirbelia oxylobioides, Dodonaea viscosa, Calytrix tetragona, Leptospermum myrtifolium and Leucopogon attenuatus in the understorey.

Notes: bilobed cotyledons, axillary inflorescences and versatile anthers place E. saxicola within the Section Maidenaria, while sessile and ovate juvenile leaves and the annular disc of the fruit place the species within the Series Bridgesianae (Pryor \& Johnson 1971). The fibrous persistent bark and the distinctly crenulate juvenile leaves allies this species with Eucalyptus angophoroides and E. bridgesiana (Chappill \& Ladiges 1996). In general morphology E. saxicola is most similar to E. bridgesiana, particular fruit shape. E. bridgesiana is common particularly at lower altitudes within the Mt Canobolas State Recreation Area but is ecologically distinct from E. saxicola in occurring on deeper soils. E. saxicola differs morphologically from the co-occurring 


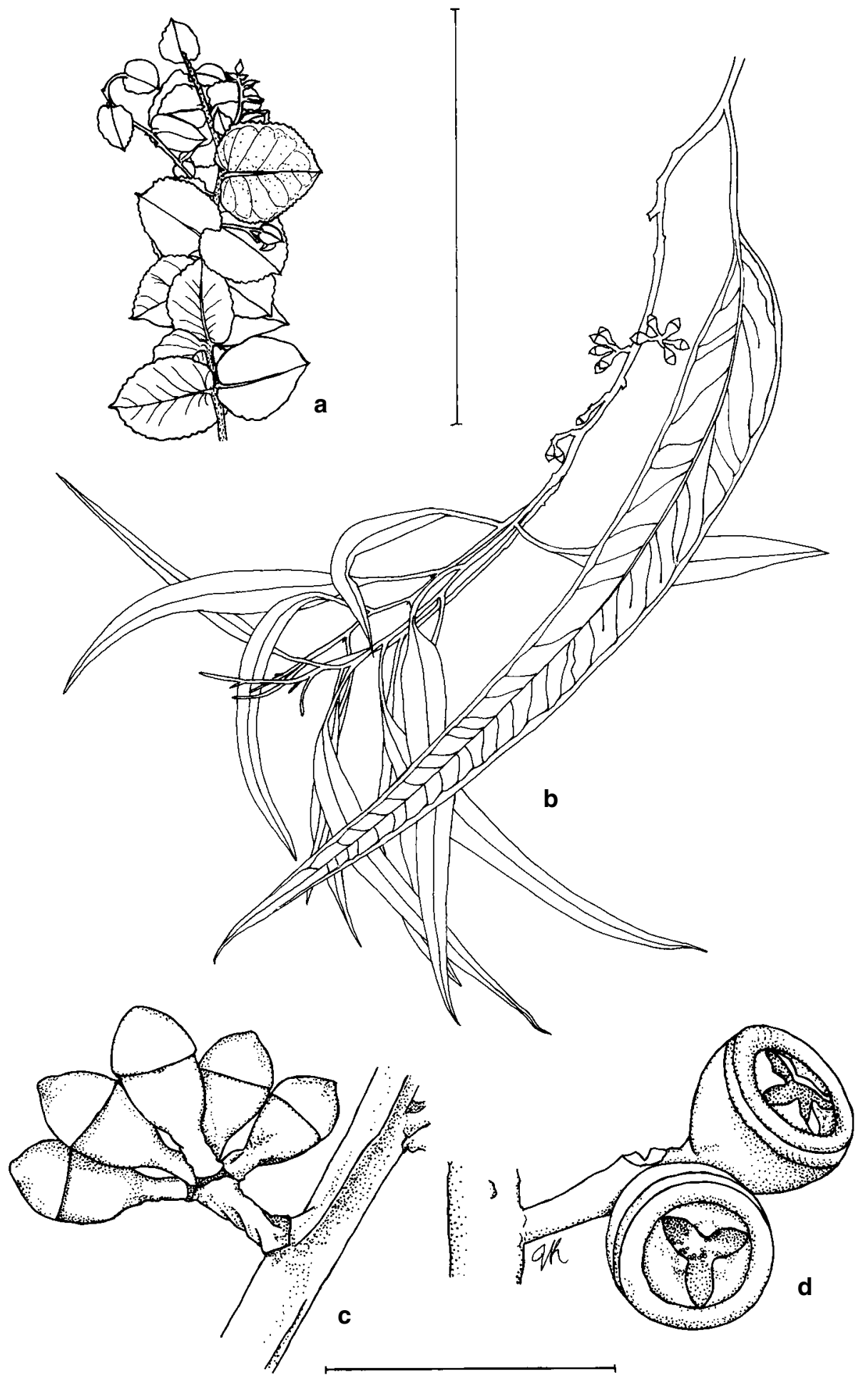

Fig 1. Eucalyptus saxicola J.T. Hunter. a, juvenile foliage; $\mathbf{b}$, adult leaf and bud arrangement; $\mathbf{c}$, bud; d, fruit (all from JTH 8556). Scale bar, a \& b = $10 \mathrm{~cm}$; c \& d = $1 \mathrm{~cm}$. Illustration by Vanessa Hunter. 
E. bridgesiana in its overall smaller stature and smaller parts such as juvenile leaves, buds and fruit (Table 1). Unlike E. bridgesiana, the calyptra is hemispherical rather than conical, being distinctly broader than long.

Table 1. Comparison of selected characters for Eucalyptus saxicola and Eucalyptus bridgesiana.

E. bridgesiana measurements based on measurement of material held at UNE and the sources Chippendale (1988), Hill (1991) and Brooker \& Kleinig (1999).

\begin{tabular}{|c|c|c|}
\hline & Eucalyptus saxicola & Eucalyptus bridgesiana \\
\hline Plant height (in m) & $6-15$ & $8-22$ \\
\hline Juvenile leaf length (in $\mathrm{cm}$ ) & $1.5-4$ & $4-10$ \\
\hline Juvenile leaf width (in cm) & $1.5-4$ & $4-8$ \\
\hline Juvenile \& sucker stems & Strongly glandular to erect warty & $\begin{array}{l}\text { Smooth to glandular } \\
\text { (some distinctly so) }\end{array}$ \\
\hline Peduncle & Flattened to ovoid & Terete to angular \\
\hline Pedicel length (in mm) & $0-3$ & $2-5$ \\
\hline Calyptra length (in mm) & $1.5-2.3$ & $3-5$ \\
\hline Calyptra width (in mm) & $2.3-2.7$ & $3-5$ \\
\hline Calyptra shape & Hemispherical, broader than long & $\begin{array}{l}\text { Conical, as long or } \\
\text { longer than broad }\end{array}$ \\
\hline Fruit length (in mm) & $3.5-5.2$ & $5-7$ \\
\hline Fruit valves & Level or rarely exerted & Exserted \\
\hline
\end{tabular}

Conservation status: Eucalyptus saxicola has a population estimated to be fewer than 200 individuals. The stands are not continuous and are scattered over an almost linear $1 \mathrm{~km}$ stretch on the northern flank of Mt Canobolas. The metapopulations of this species are likely to have been reduced in size due to road works with three major access trails passing through stands. Of particular importance is the main access road to the summit that cuts through the largest occurrence of this species. The road itself is build up and may still cause major impacts on the species. Other threats are also apparent including high visitor pressure, dumping of cars and their incineration is a regular practice, blackberry invasion and the small total population size. Other populations may have existed outside of the reserve in similar habitats that are now under extensive Pinus radiata plantation. Due to the highly restricted distribution, low population size and current impacts on the population by road works and visitor pressure an initial ROTAP code of 2ECt according to the criteria of Briggs and Leigh (1996) is suggested. Inclusion on the Threatened Species Conservation Act 1995 as Endangered would be desirable.

Etymology: the specific epithet is from the Latin, saxum meaning stone, rock and cola, dweller, and is in reference to the highly restricted occurrence of this species on and around the margins of rock outcrops.

\section{Acknowledgments}

Project management of the two surveys was by Amanda Bryant and assistance in the field was given by Steve Woodall both of the Central West Region of the New South Wales National Parks and Wildlife Service of New South Wales. Thanks to Vanessa 
Hunter for illustrations. Thanks also to the heads of NSW and CANB for allowing access to collections of Eucalyptus during the threatened species of the Central Tablelands project. The resources of UNE herbarium were used for measurements of E. bridgesiana.

\section{References}

Briggs, J.D. and Leigh, J.H. (1996) Rare or Threatened Australian Plants, revised edition. (CSIRO Publishing: Collingwood).

Brooker, M.I.H. \& Kleinig, D.A. (1999) Field Guide to Eucalypts Vol. 1. (Bloomings Books: Hawthorn). Chappill, J.A. and Ladiges, P.Y. (1996) Phylogenetic analysis of Eucalyptus informal Subgenus Symphyomyrtus Section Maidenaria. Australian Systematic Botany 9: 71-93.

Chippendale, G.M. (1988) Eucalyptus, Angophora (Myrtaceae). Flora of Australia 19. (AGPS: Canberra).

Hill, K.D. (1991) Eucalyptus. Pp. 76-142. In Harden, G.J. (ed.) Flora of New South Wales Vol. 2. (University of New South Wales Press: Sydney).

Hunter, J.T. (2000) Vegetation and Floristics of the Mt Canobolas State Recreation Area. Unpublished report for the Western Directorate New South Wales National Parks and Wildlife Service (Dubbo).

Hunter, J.T. (1998) Threatened Endemic Eucalyptus of the Central Tablelands. Unpublished report for the Western Zone New South Wales National Parks and Wildlife Service (Dubbo).

Pryor, L.D. \& Johnson, L.A.S. (1971) A Classification of the Eucalypts. (The Australian National University: Canberra).

Manuscript received 14 August 2000

Manuscript accepted 29 March 2001 